\title{
Analysis of Web-based College English Teaching from 2000 to
}

\section{7 in China}

\author{
Baohuan Zhang \\ Department of College English Teaching, Qufu Normal University, Rizhao 276826, \\ China \\ zhangbh@qfnu.edu.cn
}

\begin{abstract}
Based on 812 papers on web-based college English teaching published in Chinese journals from 2000 to 2017, this study adopted modern statistical methods to explore the spatio-temporal development of the research. The results revealed the research on web-based college English teaching started in 2000 and had been increasing from 2006 to 2011; however, scholars' attention to it was on the decline after 2012. During the period of 2000-2017, the average annual number of papers published in Chinese journals was up to 45 while that in core journal was only 4 . Meanwhile, there were significantly spatial differences. The research on web-based college English teaching in China has mainly focused on eastern region, particularly, Beijing and Guangdong as two main research regions, and its average annual number of papers issued in core journals accounted for $9.5 \%$ of the total amount of the country respectively. We can see many well-known experts in "double first-class" universities pay little attention to the research on web-based college English teaching and there are weak foundation and low faculty. In recent years, college English teaching has been closely related to internet, also, colleges and universities increasingly put more emphasis on the significant influence of network on college English teaching, and however, the research level of web-based college English teaching needs to be improved further from the perspective of the quality and quantity of the published papers.
\end{abstract}

Key words:college english teaching, network, spatio-temporal differences

\section{INTRODUCTION}

College English as a subject has a large audience and high social attention in Chinese Higher Education(Wang, 2002). The General Office of the Ministry of Education in Document No. 4 of 2006clearly pointed out that the reform of college English teaching is an important part of the "teaching reform and teaching quality engineering of higher education institutions" of the Ministry of 
Education and makes an important contribution to leading and promoting the reform of higher education teaching in China and cultivating high-quality personnel. In 2013, the Ministry of Education formulated the "Guiding Opinions on Further Deepening the Reform of College English Teaching", which set clear requirements for the application of advanced modern teaching methods and teaching models (Bao, 2016). It can be seen that with the rapid development of modern technologies, the application of methods and means such as network technology and network teaching mode has played an important role in college English teaching (Sui, 2013; Jia, 2016; Wang, 2016). Therefore, in order to adapt to the new goals and new requirements of college English teaching reform, it is of great practical significance to strengthen the research on web-based college English teaching for formulating the reform strategy and promotingits smooth development.

In recent years, the research on web-based college English teachinghas attracted some scholars' attention. For example, Chen and Wang (2016) studied the normal changes and development in the process of education informatization in foreign language; Sun (2017)tested and analyzed the satisfaction inventory of network self-learning platform oncollege English; Li (2013) discussed the application of college English teaching under the environment theory of multi-modal network; Jia (2011) analyzed the problems and solutions of college English teaching based on network eclectic model; Li (2008) studied how to use online teaching to help English learner relieve anxiety and improve reading ability. Previous research showed that college English teaching and networkwere inseparable; meanwhile, although some scholars have carried out many useful discussions on web-based college English teaching in China, its current status and problems need to be further analyzed.

Therefore, based on modern statistics methods, we analyzed the quality and quantity of paper based on network English teaching as well asits spatial-temporal distribution,and revealed the status quo ofbasic research level and faculty and facilities of university in China. The research results can provide a scientific reference for promoting the reform of college English teaching and the development of the research on college English network teaching in China.

\section{METHOD}

The source of the literature was fromChina National Knowledge Infrastructure (CNKI), which wasthe most comprehensive system of China Knowledge resources-China Integrated Knowledge Resources Database. CNKI as retrieval platform, we used Chinese Journal Full-text Database, Chinese Doctoral Dissertation Full-text Database and Chinese Excellent Master's Thesis Full-text Database as data sources and chose "college English teaching" or "university foreign language teaching" or "public foreign language teaching" or "public English teaching" as the titlesand searched"network" and "web-based" as key words. The published papersbefore December 15, 2017 were carried out an 
"exact" academic search. The selection "title" as a search term was to ensure all searched papers to be web-based college English teaching. There were two reasons for time setting: on the one hand, there was no limit on the start time of the search, in order to figure out the start time of the research on network-based college English teaching from the search results; on the other hand, in order to demonstrate the latest developments in the study,academic search day (December 15, 2017) wasconsidered as the end time of the results analysis.

After conducting the academic searchaccording to the above method, we obtained a total of 812 academic papers on network-based college English teaching published from January 1, 2000 to December 15, 2017 actually. In addition, "core papers" were selected to retrieve 74 core papers and 18 dissertations. There are a few dissertations, maybe that's because the dissertations of some universities or research units are not yet included by China Knowledge Network. Thus, this study did not conduct relevant analysis on dissertations.

Bibliometric analysis method wasemployed to quantitatively analyze the development of web-based college English teaching in China. The search data were imported into Excel for statistics, sorting and categorization, and ArcGIS software was used to explore the spatial distribution of the results.

\section{RESULT}

\section{Keyword co-occurrence analysis}

The idea of co-occurrence analysis comes from the citation coupling and co-citation concept of bibliometrics, that is, when two keywords that can express the research topic or research direction of a subject field appear in the same document, it indicates that there is a certain intrinsic relationship between words, and the more frequently they occurred, the closer the relationship is (Yin, Zhang \& Ren, 2011). "College English" and "College English Teaching" are two core keywords, with the most frequent occurrences, 250 and 201 respectively. Two core keywords are closely related to "network" and "teaching mode", and the number of co-occurrences is 134 and 148 respectively; followed by the number of co-occurrences of two core keywords with"network environment" (81 times), and then with"multi-media" (93 times), "English teaching" (68 times) and "self-directed learning" (75 times). It can be seen that college English teaching has become an integral part of internet.

\section{Statistical analysis of the number of papers}

The search results showed that the research on network-based college English teaching in China began in 2000. During the period of 2000-2017, the average number of research papers was 45.1 (Figure 1), and the overall trend increased first and then decreased. Meanwhile, in 2000-2005, the research was in the initial stage of development. The number of annual publications was from 2 at the beginning of 2000 to 30 in 2005, the average annual volume of 
publications was 11.1, which was consistent with the research conclusions of Chen Jianlin and Wang Jing:"The period of 1999-2004 was the initial stage of Chinese educational informatization research"(Chen \& Wang, 2016). In 2006-2011, the number of papers was at a high level of volatility and the average annual volume was78.9 articles. In addition,the number of papersreached a maximum of95 in 2010, in this sense, teaching informatization research has entered into a new stage from the beginning to the application (Chen \& Wang, 2016). Meanwhilethis period was also an explosive growth stage of college English teaching research in China, with an average of 2,000 articles per year (Huang, 2014). It can be seen that the papers on web-based college English teaching accounted for a relatively small proportion of the total number of college English teaching research. In 2012-2017, the number of papers showed a decreasing trend, with an average annual volume of 45.3 , which was nearly equivalent tothe average level ofmulti-year. Although the research on teaching informationization in China has entered the stage of comprehensive integration in recent years (Chen \& Wang, 2016), the number of research papers on web-based college English teaching has been declining, which is worthy to think deeply and concern of problem.

Over the past 18 years, the change trend of core papers has been consistent with the trend of the total number of journal papers and increased firstly and then decreased. However, from the perspective of annual publications, the number of published core papers was significantly smaller and was only 4.1, less than $10 \%$ of the total annual number of papers. However, in 2006-2010, the average annual volume of core papers was relatively high and up to 6.8.

The above analysis showed that the popularity of network-based college English teaching research in China was only relatively high in 2006-2011, but the quantity and quality of research papers were not high. Moreover, the attention-degree of the research has decreased in recent years.

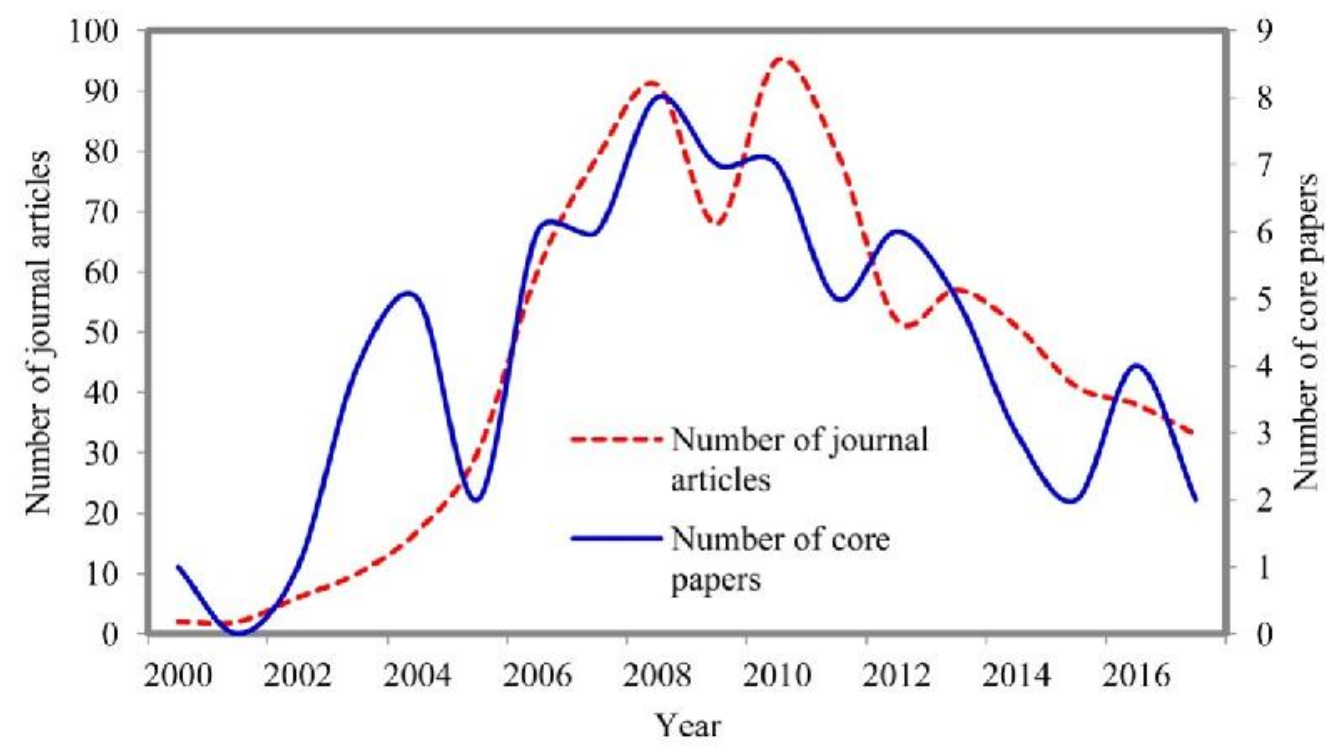

4 ENGLISH EDUCATION Journal of English Teaching and Research 
Figure1.During 2000-2017 Number of Papers on Web-based College English Teaching Published

\section{Statistical analysis of core journals}

In 2000-2017, there were 74 articles published in 37 different core journals (Figure 2). A total of 53 papers published in the top 16 journals accounted for $71.6 \%$ of the total number of publications. Among the core journals, the "China Adult Education" and "Education and Vocation" journals have the largest number of articles and were 8 and 7, respectively, followed by 5 published articles in "Foreign Languages World" and "Theory and Practice of Education ". Foreign Language and Foreign Language Teaching, China University Teaching, and Computer-Assisted Foreign Language Education published 2-3 articles, respectively. In addition, from a disciplinary perspective, published journals mainly focused on foreign languages and literature, followed by educational theory and educational management. In general, the number of papers published in core journals is very small.

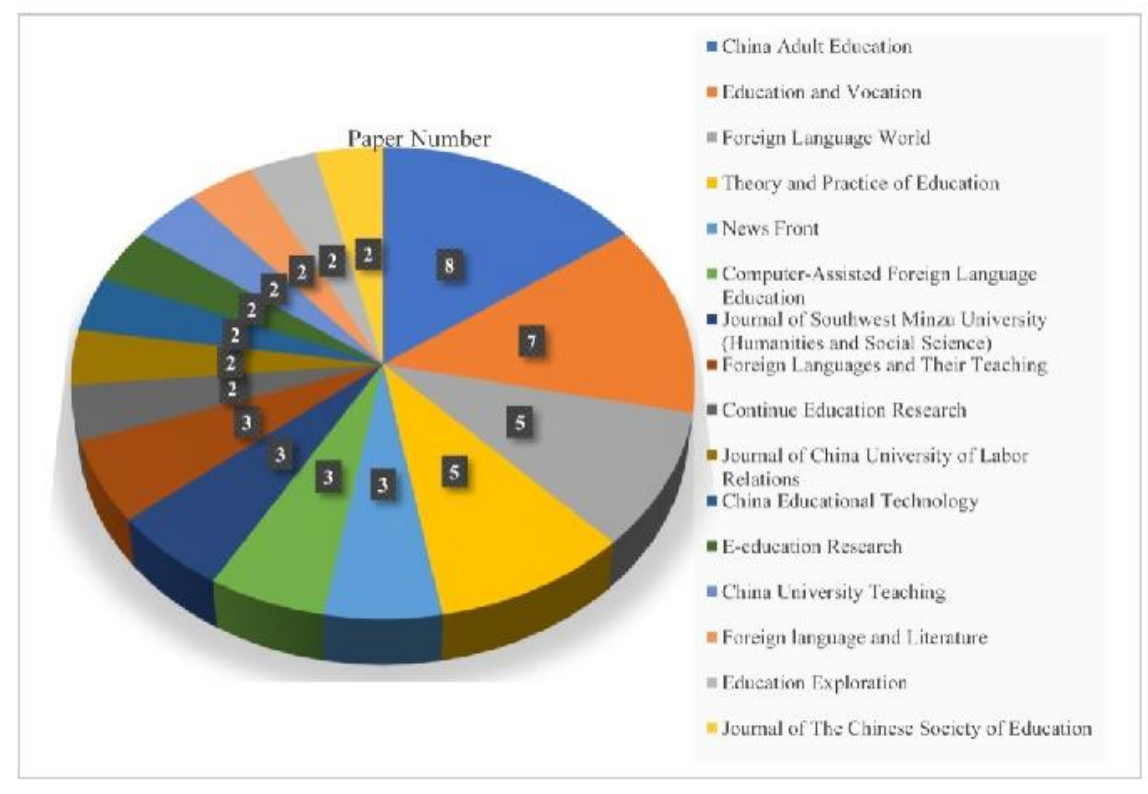

Figure 2. Distribution of core journals on web-based college English teaching from 2000 to 2017 (top 16)

\section{Analysis of regional differences in core papers}

In this study, a percentage of the number of core papers published by each province to the total number of core papers revealed regional research differences from 2000 to 2017. According to the regulations of the National Bureau of Statistics, China's mainland is divided into four regions: the eastern, central, western and northeast regions. The eastern region includes 10 provinces (municipalities), such as Shandong, Guangdong, Beijing, Tianjin, Hebei, Jiangsu, Zhejiang, Shanghai, Fujian and Hainan; the central region includes six provinces, such as Jiangxi, Henan, Anhui, Shanxi, Hubei and Hunan; the western region 
includes 12 provinces (autonomous regions and municipalities), such as Xinjiang, Guangxi, Chongqing, Guizhou, Gansu, Yunnan, Tibet, Shanxi, Sichuan, Qinghai, Ningxia and Inner Mongolia; Northeast China includes Liaoning, Jilin and Heilongjiang provinces.

From the published papers in 2000-2017, the core papers in the eastern region were published the most (Figure 3) and the number was 38, accounting for $51.4 \%$, followed by 16 in the western region, accounting for $21.6 \%$, while the numbers of core papers in the central and northeast regions are 12 and 8 respectively, accounting for $16.2 \%$ and $10.8 \%$ respectively. It can be seen that the spatial differences in the research on college English online teaching in China are significant. The eastern region was the main region for publishing the relevant paper, which was related to the higher level of social and economic development in the region and the large number of population and higher education institutions. Although there were more core papers in the western region than in the central and northeastern regions, the western region includes 12 provinces, far more than six provinces in the central region and three provinces in thenortheastern region. Therefore, the relevant research in the western region was still the least, followed by the central region. Therefore, the central and western regions should further strengthen the research on college-based English teaching.

As for the number of core papers published by provinces, municipalities and autonomous regions, Beijing and Guangdong havethe largest number, accounting for $9.5 \%$ of the total number of core papers; followed by Zhejiang (6.8\%), Jiangxi (6.8\%), Shandong (5.4\%), Sichuan (5.4\%), Shanghai $(5.4 \%)$ and Heilongjiang (5.4\%); there were a small amount of papers or not,such as Xinjiang (1.4\%), Ningxia (1.4\%), Gansu (1.4\%) Chongqing (1.4\%), Hubei (1.4\%), Hunan (1.4\%), Guizhou (1.4\%), Fujian (1.4\%), Anhui (1.4\%), Qinghai (0), Yunnan (0), Tibet (0). It can be seen that the amount of Fujian's publications in the eastern region was somewhat unexpected, which was not consistent with its economic development level; the papers in Heilongjiang of the northeast region occupied the certain proportion; the number of papers in the central region was generally small, however, in the western region,only Sichuanranked the top of the country. 


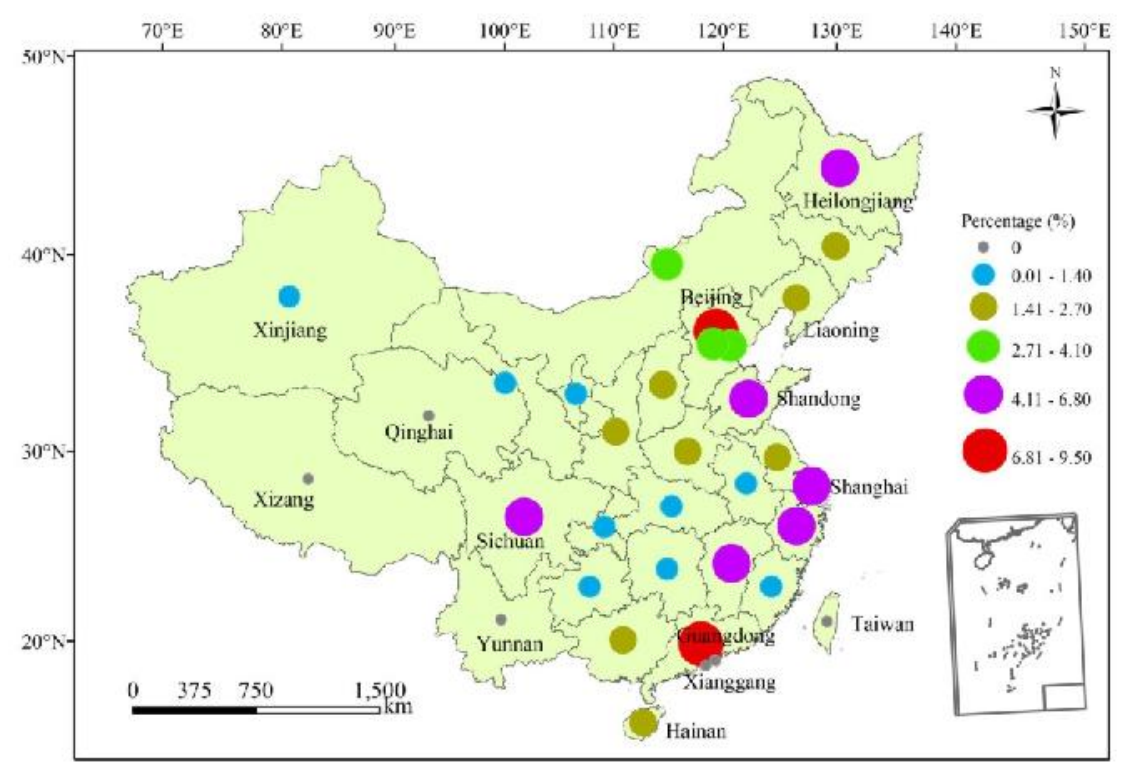

Figure 3. Spatial distribution of core papers on web-based college Englishteaching research from 2000 to 2017

\section{Statistical analysis of paper citation frequency}

Besides the journal level of published papers, the number of citations of papers has been widely used to measure the quality or influence of academic papers. Therefore, this study focused on the top 15 citations of the paper on network-based college English teaching in 2000-2017 (there were 16 articles at the top 15 because of the phenomenon of articles with the same frequency of citation). The analysis showed that the frequency of citations of the top 15 papers was significantly different (Table 1). Among them, Chen Jianlin's papers published in Computer-assisted Foreign Language Education were cited the most and up to 324 times; followed by Zhang Hua's paper published in Computer-assisted Foreign Language Educationwith 224 times and Jia Guodong published in Foreign Languages World with 208 times, Fu Lingfang and Yang Shen published in Foreign Languages and Foreign Language Teaching with 188 times; and the paper published by Jia Guodong and An Qi ranked No. 15 and the cited frequency was 25 times. The results showed: (1) The high-cited papers were basically published in the core journals and had more influence; (2) The citation frequency of top 15 high-cited papers was not "high" in general, which may be related to scholars' little attention to the relevant research; (3)Most of papers have only one author, indicating there was less cooperation among scholars, and it was more difficult to form the core groupof authors; (4)few authors whose paper cited frequency ranked top 15 belong to"Double Top-Class" colleges and universities whilewell-known experts paid less attention to the research on web-based college English teaching, which indirectly reflects weak foundation and low faculty of the research. 
Table 1. Citation frequency statistics of theresearch paperson networkbased college English teaching from 2000 to 2017 (top 15)

\begin{tabular}{|c|c|c|c|c|}
\hline Rank & Authors & Author's unit & Journal & $\begin{array}{l}\text { Cited } \\
\text { times }\end{array}$ \\
\hline 1 & $\begin{array}{l}\text { Chen Jianlin } \\
\text { (2006) }\end{array}$ & $\begin{array}{c}\text { Shanghai Foreign Speech } \\
\text { Press }\end{array}$ & $\begin{array}{l}\text { Computer-Assisted Foreign } \\
\text { Language Education }\end{array}$ & 324 \\
\hline 2 & $\begin{array}{l}\text { Zhang Hua } \\
\text { (2003) }\end{array}$ & Foshan University & $\begin{array}{l}\text { Computer-Assisted Foreign } \\
\text { Language Education }\end{array}$ & 224 \\
\hline 3 & $\begin{array}{c}\text { Jian } \\
\text { Guodong(2003) }\end{array}$ & $\begin{array}{c}\text { South China University of } \\
\text { Technology }\end{array}$ & Foreign Language World & 208 \\
\hline 4 & $\begin{array}{c}\text { Fu Lingfang, } \\
\text { Yang } \\
\text { Jianding(2007) }\end{array}$ & Shaoxing University & $\begin{array}{l}\text { Foreign Languages and } \\
\text { Their Teaching }\end{array}$ & 188 \\
\hline 5 & $\begin{array}{c}\text { Zhu } \\
\text { fudao(2004) }\end{array}$ & $\begin{array}{l}\text { Guangdong Polytechnic } \\
\text { Normal University }\end{array}$ & Foreign Language World & 135 \\
\hline 6 & $\begin{array}{c}\mathrm{Li} \\
\text { Menghua(2007) }\end{array}$ & Xidian University & $\begin{array}{l}\text { Computer-Assisted Foreign } \\
\text { Language Education }\end{array}$ & 60 \\
\hline 7 & $\begin{array}{c}\text { Wang } \\
\text { Yanping(2006) }\end{array}$ & Xidian University & Foreign Language World & 56 \\
\hline 8 & $\begin{array}{l}\text { Wang Zhe, Xia } \\
\text { Jimeng(2010) }\end{array}$ & Sun Yat-sen University & $\begin{array}{l}\text { Computer-Assisted Foreign } \\
\text { Language Education }\end{array}$ & 49 \\
\hline 9 & $\begin{array}{c}\text { Liu Wenyu, } \\
\text { Xiang } \\
\text { Bibi(2000) }\end{array}$ & $\begin{array}{l}\text { Dalian University of } \\
\text { Technology }\end{array}$ & $\begin{array}{l}\text { Foreign Languages and } \\
\text { Their Teaching }\end{array}$ & 41 \\
\hline 10 & Qin Leyu(2004) & Central South University & $\begin{array}{l}\text { Modern University } \\
\text { Education }\end{array}$ & 37 \\
\hline 11 & $\begin{array}{c}\text { Wang } \\
\text { Boran(2010) }\end{array}$ & Northeastern University & $\begin{array}{l}\text { Journal of Northeastern } \\
\text { University (Social Science) }\end{array}$ & 36 \\
\hline 12 & $\begin{array}{c}\text { Zhang } \\
\text { Hua(2002) }\end{array}$ & Foshan University & $\begin{array}{l}\text { Modern Educational } \\
\text { Technology }\end{array}$ & 32 \\
\hline 13 & $\begin{array}{c}\text { Wu } \\
\text { Yingjie(2006) }\end{array}$ & $\begin{array}{c}\text { Jilin Institute of Chemical } \\
\text { Technology }\end{array}$ & Modern Education Science & 31 \\
\hline 14 & $\begin{array}{c}\text { Xiao } \\
\text { Rongliang,Yu } \\
\text { Zhen(2002) }\end{array}$ & Shantou University & Foreign Languages Research & 29 \\
\hline 15 & Jian Guodong & Renmin University of China & China University Teaching & 25 \\
\hline
\end{tabular}


|Volume: 5 |Number: 1 |May 2020 |E-ISSN: 2503-4405 |P-ISSN: 2580-3441 |

\begin{tabular}{|c|c|c|c|c|}
\hline & (2009) & & \\
\hline 15 & An Qi (2009) & $\begin{array}{c}\text { Harbin University of } \\
\text { Commerce }\end{array}$ & $\begin{array}{c}\text { Computer-Assisted Foreign } \\
\text { Language Education }\end{array}$ & 25 \\
\hline
\end{tabular}

\section{Analysis of Regional Differences in High- Cited Papers}

In order to further clarify regional differences in the research on college English online teaching in China; this study analyzed the percentage of the number of high- cited papers in each province to the total number of cited papers. High-cited papers in this study referred to top 100 cited in 812 journal papers and actual citation frequency was between 6 and 324 times. Since the number of citations is the same, there are 109 cited papers in the top 100.

From the number of publishedpaper in 2000-2017, the core papers in the eastern region were published the most (Figure 4), reaching 42 articles and accounting for $38.5 \%$, followed by the central region and the number was 27 , accounting for $24.8 \%$, while There are fewer core papers in the western and northeast regions and the number were 19 and 21 respectively, accounting for $17.4 \%$ and $19.3 \%$ respectively. It can be seen that the eastern region was the main region to study on network-based college English teaching. Although the proportion of core papers in Northeast China was lower than that in the central and western regions, the average proportion of provinces in Northeast China was significantly higher than that in the central and western regions, indicating that the relevant research level in Northeast China was still significantly higher than these areas.

Based on the number of high-cited papers published in different provinces, municipalities and autonomous regions, the number of the published paper in Guangdong reached the highest, accounting for $10.1 \%$ of the total number of high-cited papers; followed by Zhejiang (7.3\%) Liaoning (7.3\%), Jiangsu (6.4\%), Hubei (6.4\%), Henan (6.4\%) and Heilongjiang (6.4\%); Hebei (1.8\%), Shandong (1.8\%), Fujian (1.8\%), Shanxi (1.8\%), Anhui (1.8\%), Chongqing (1.8\%), Sichuan (1.8\%), Gansu (1.8\%), Xinjiang (1.8\%), Inner Mongolia (0.9), Guizhou (0.9), Yunnan (0.9), Tianjin (0), Hainan (0), Tibet (0), Qinghai (0) and Ningxia (0). It can be seen that Shandong, Hebei, Anhui, and Fujian in the eastern region have fewer publications, in particular, Shandong asone of the most populous province and an economically and scientifically powerful province in China, it was not consistent with its research level; Liaoning and Heilongjiang in Northeast China showed the higher number of paper while the number of papers in Henan and Hubei in the central region was relatively high, however, the total number of high-cited papers in the western region wasvery low. 


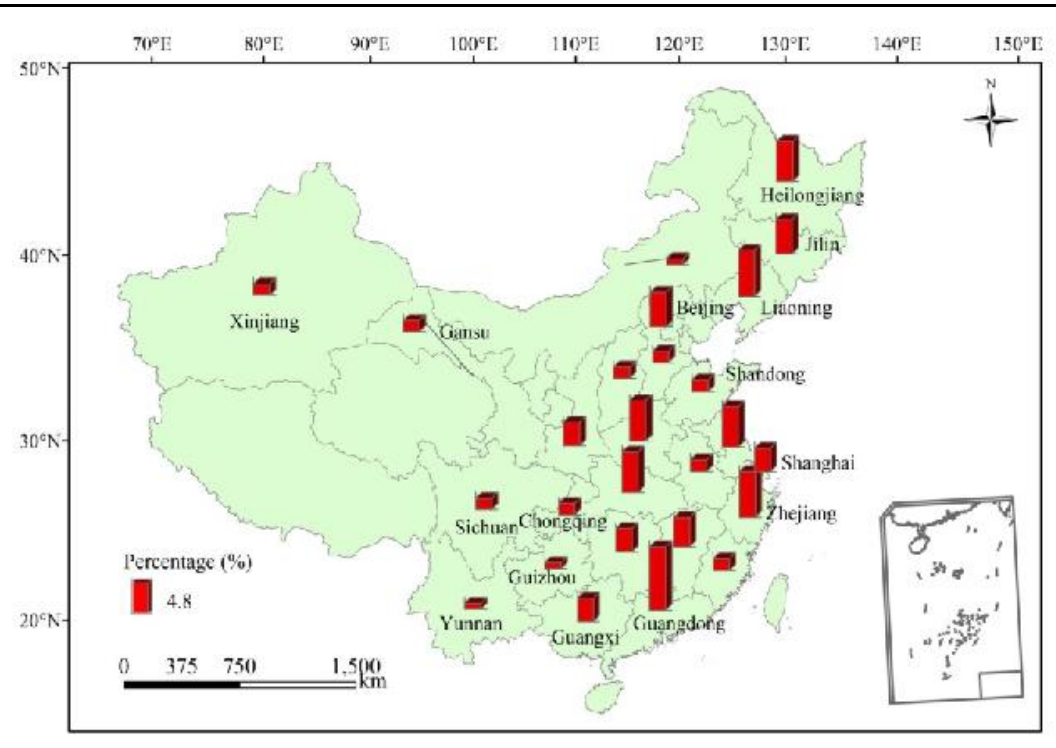

Figure 4. During 2000-2017 Spatial Distribution of Highly Cited Papers (Top 100)

\section{CONCLUSION}

The research on web-based college English teaching in China began in 2000. In 2006-2011, the number of papers was at a high level of volatility, with an average of 78.9 articles per year. From 2012 to 2017, the number of papers in the study showed a decreasing trend, with an average annual volume of only 45.3. The level is equivalent to the average level of multi-years. The number of core papers was significantly less than $10 \%$ of the total annual number of papers, and the quality of the papers is not high. In general, although college English teaching has been inseparable from the network, this research has not only weak faculty but also low research level.

There are significant spatial differences in the study of web-based college English teaching in China. The eastern region is the main regionto publish the relevant papers while the central and western regions need to be strengthened. From the perspective of provinces, municipalities and autonomous regions, Beijing and Guangdong have the largest number of papers, respectively accounting for $9.5 \%$ of the total number of core papers,moreover, unexpectedly, the number of papers in the eastern region was only $1.4 \%$, which was not consistent with its level of economic development.

\section{REFERENCES}

An, Q.(2009). An Empirical Study Based on College English Teaching with the Background of Networks. Computer-Assisted Foreign Language Education, 3,58-62.

Bao, W. (2016). Reconstruction of College English Teachers' Belief against the Background of Connotative Development. Journal of Jilin Engineering Normal 
|Volume: 5 |Number: 1 |May 2020 |E-ISSN: 2503-4405 |P-ISSN: 2580-3441 |

University, 32(9), 19-20.

Chen, J. L., \&Wang, J. (2016). On the Development of “Normal” in IT-based Foreign Language Education. Computer-Assisted Foreign Language Education, 2,3-9.

Chen, J. L. (2006). On the Integration of Computer and Internet into Foreign Language Teaching Program-From an Ecologic. Technology Enhanced Foreign Language Education, 6,3-10.

Fu, L. F.,\&Yang, J. D. (2007). Research on Autonomous Learning Ability Based on Network Multimedia College English Teaching Model. Foreign Languages and Their Teaching, 10,36-38.

Huang, L. (2014). On the 30-year Development of College English Teaching Research in China (1983-2012). Foreign Language World, 6,57-65.

Jia, G. D. (2009). College English teaching model based on classroom and network. China University Teaching, 6,82-85.

Jia, G. D. (2016). Methods,means and resources of English teaching in the Guidelines on College English Teaching. Foreign Language World, 23, 11-18.

Jia, G. D. (2003). Modern Network Technology and the Reform of College English Teaching Model--Design and Experimental Research Based on Campus Network Teaching Model. Foreign Language World, 6, 22-29.

Jia, G. D. (2011). Research on Network-based Eclectic College English Teaching Model. China University Teaching, 6,75-77.

Li, C. G. (2013). Study on the Application of Multimode Learning Environment Based on Internet to the College English Teaching for Music, Sports and Arts Majors. Technology Enhanced Foreign Language Education, 5, 71-75.

Li, L. (2008). The Effect of Network-based Language Teaching on ReadingCompetence-a Study of How to Lower Learners' ForeignLanguage Anxiety. Guizhou University.

Li, M. H. (2007). College English Teaching Based on Computer Network. Technology Enhanced Foreign Language Education, 1,32-35.

Liu, W. Y, \&Xiang, B. H. (2000). Network and College English Teaching. Foreign Languages and Their Teaching, 10,62-62.

Qin, L.Y. (2004). Thoughts on College English Teaching Model Under the Environment of Multimedia Network Technology. Modern University Education, 4,107-109. 
Sui, X. B. (2013). The Optimization Research on Web-based College English Classroom Teaching--an Empirical Study in Jiamusi University. Shanghai International Studies University.

Sun, Z. N. (2017). Learners' Satisfaction Towards College English Autonomous Learning Platform. Technology Enhanced Foreign Language Education, 3, 15-21.

Wang, B. R. (2010). Application of Project-based Learning to College English Teaching in the Networked Environment. Journal of Northeastern University(Social Science), 12(2), 168-172.

Wang, H. X. (2016). The Practice and Effect of College English Teaching Reform Under the Background of "Internet +". English Square, 08, 115-116

Wang, Q.M. (2002). Reasons for Ineffective College English Teaching and Relevant Countermeasures. Foreign Language World, 4,27-35.

Wang, Y. P. (2006). Research on Evaluation System of College English Teaching under the Environment of Multimedia Network. Foreign Language World, S1, 117:96-107.

Wang, Z., \&Xia, J.M. (2010). The Effects of College English Teaching-learning by Combination ofNetwork and Classroom. Computer-Assisted Foreign Language Education, 3,13-20.

Wu, Y. J. (2006). Discussion on College English Teaching Model Based on Computer Network. Modern Education Science, 1,100-103.

Xiao, L. R., \&Yu, Z. (2002). On the Opportunities and Challenges Brought by Computer Network Technology to College English Teaching. Foreign Languages Research, 5, 66-69.

Yin, S. Q., Zhang, J. L., Ren, L. (2011). Research Hotspots Analysis of Digital Library Based on Keywords Co-occurrence Analysis and Social Network Analysis. Journal of Academic Libraries, 29(4), 25-30.

Zhang, H. (2003). Exploration of College English Teaching Model under the Environment of Multimedia and Network. Computer-Assisted Foreign Language Education, 2,37-40.

Zhang, H. (2002). Web-based College English Teaching. Modern Educational Technology, 12(4), 49-52.

Zhu, F. D. (2004). The Leading Role of Teachers in Network-assisted College English Teaching. Foreign Language World, 1, 48-53.

12 ENGLISH EDUCATION

Journal of English Teaching and Research 